\title{
Changing Global Trade Landscape: Developing Country Perspective
}

\author{
Mari Elka Pangestu ${ }^{\dagger}$ \\ Faculty of Economics and Business \\ University of Indonesia \\ Jakarta, Indonesia \\ mari@pangestu.net
}

\begin{abstract}
The current global trade landscape is changing rapidly with the escalating US-China trade war, technological disruption, and changing global trade pattern. This has raised question on whether the current multilateral framework is adept to these new issues, and what are the developing countries' best policy response in facing these challenges. This paper provides the background of the changing global trade landscape and suggests that countries shall take a three-pronged approach: unilateral reforms, regional partnership, and strengthening multilateral trading system.
\end{abstract} System

Keywords-Trade War, WTO Reform, Multilateral Trading

\section{INTRODUCTION}

For the last seven decades trade took place under a multilateral economic order emerging from the tariff wars of the Great Depression. The Bretton Woods was created 75 years ago, with the creation of GATT (General Agreement Trade and Tariffs) which was followed by the establishment, the World Trade Organization (WTO) in 1995. This current system is facing an unprecedented threat from the major countries who in the past were the main defenders. In the last few years we have seen Brexit, the escalation of the USChina trade war, and the current US unilateral stance on trade policies, as well as its lack of support of the WTO as evidenced by blocking the nomination of appellate body judges for dispute settlement. These threats pose substantial risks for developing countries which have enjoyed the benefits of a predictable, open and rules-based trading system.

The challenges to the WTO and the current Multilateral Trading System, as will be argued throughout this paper, is not an exogenous shock that took place because of the current US stance, but that cracks in the system had been growing in the last decade with skepticism towards the multilateral trading system.

This paper starts by explaining the changing nature of global trade in recent years, followed by the background of the increased criticism and weaknesses that had emerged of current global trading system. This paper then explores the areas in which the current WTO framework needs strengthening and improving to address the current challenges, including the ones which underlie the US-China tensions. The paper thus provides areas of policy options that can be taken especially by developing countries in navigating through the escalating US-China trade relation and the deteriorating confidence in the Multilateral Trading System.

\section{CHANGING CONTEXT OF GLOBAL TRADE ENVIRONMENT}

\section{A. Background: Changing Pattern of Trade}

It is widely accepted that trade liberalization and reforms which have been shaped by a country's WTO commitments and its process of WTO accession, have yielded substantial economic benefit, and lifted millions out of poverty ${ }^{2}$. The most cited experience is the role of trade in the rapid growth and development in East Asia. After its WTO accession, the size of China's economy increased six-fold from 2001-2017. Meanwhile the nominal value of its imports and exports grew at 25 percent p.a. and increased tenfold over 1992 to 2017 from $\$ 165$ billion to US\$ 1.7 trillion $^{3}$. In the rest of East Asia the role of promoting international trade and opening up to foreign investment since the $1980 \mathrm{~s}$, on lifting the millions of people out of poverty and raising living standards at remarkable speed is also well documented. ${ }^{4}$

However, there appears to be a slowdown in the growth of trade in the last 8 years. After the Global Financial Crisis (GFC), world merchandise exports grew by only 5.6 percent on average between 2010 to 2018 compared to an average growth of $12.2 \%$ pa over the $2000-2008$ period. The share of world merchandise trade to GDP grew from 39 percent in 2000 to 51.4 percent in 2008. Since then, the share has declined, reaching 46.2 percent in 2018 - lower than in 2006, where the share was at 47.7 percent $^{5}$.

A study by Constantinescu, et al (2018) found not only did global trade has been slowing down, but the relationship between trade and income has also declined. Between 1970 and 1985 , a 1 percent increase in trade increases income by

\footnotetext{
$\dagger$ This paper has been written with excellent research assistance from Nabil Rizky Ryandiansyah

${ }^{2}$ See, for example, Amiti and Konings (2007) and Dutt, et al (2013) that found that trade liberalization has given substantial
}

increase in productivity and the extensive margins of trade

${ }^{3}$ In 2001, its export share of GDP was at roughly 20 percent. It peaked on 2006 at 36 percent but then gradually declined. As of
2017 , the number is slightly below 20 percent.

${ }^{4}$ See Birdsall, et al (1993) and Stiglitz and

Yusuf (2001)

${ }^{5}$ Data from WDI World Bank 
1.3 percent. The number surged between 1986 to 2000 to 2.2 . However, from 2000 onwards, the elasticity dropped back to 1.3. Decomposing between pre-GFC and post-GFC period, it was found that the trade-to-GDP elasticity was 1.5 between 2000 and 2007, and dropped to 0.7 beginning 2008 onwards. The study also uses an error correction model to disentangle between cyclical and structural components of trade growth, and found that while much of the trade collapse in 2008 and 2009 can be explained by cyclical factors, almost half of the slow trade performance since 2013 was due to long-term structural factors.

The paper also goes further by looking at the disaggregated data to explore whether there are regional differences in these patterns. While the structural break happens in both developed and developing countries, significant changes in long-run world elasticities can be attributed to two major countries - China and the US. The two countries combined made up 33 percent of the change in the world trade elasticity in 1990 s and 40 percent of the change in 2000s. In the same period, the elasticity of US dropped from 3.7 to 1.8 , while that of China also dropped from 1.5 to 1.1. It is also worth noting that although Euro Area also comprises large share of world trade, its elasticity has been instead increasing.

The same paper described previously found that the main force of the decline in world trade elasticity was contributed by the fall in goods trade elasticity. Several factors may have contributed to this structural break, such as changes in composition of aggregate demand, with sharp decline in investment post-GFC and increase of government spending, changes in trade policies where developed countries start to resort back to protectionism, or the maturation of the Global Value Chain (GVC) and changes in vertical specialization. Comparing these plausible explanations, the paper found that it is the change in vertical specialization that contributes the most to this pattern, as much as one-quarter and one-half of the decline in import growth from the 1990s to the 2000s.

It is not far-fetched to link the fall in goods trade elasticity with maturation of GVC. For the case of China alone, its share of imports of parts and components dropped from 60 percent in mid-1990 to 35 percent in 2013. Furthermore, Kee and Tang (2016) has also found that domestic content of China's exports increased from 65 percent in 2000 to 70 percent in 2007. Moreover, Timmer, et al (2016) even found that the international fragmentation halted since 2011. The stalling fragmentation process is also not driven by any particular production process, but distributed evenly in industrial sectors. As countries rely less on foreign-produced intermediate goods, trade declines and so does the income it brings.

Figure 1 illustrates this issue. Although the GFC brought down the foreign value added in total exports, the number kept on rising until 2011, when it started to stagnate until the latest estimate in 2015. This pattern is not unique to China, but other countries such as US and Thailand as well. For the case of China, the value of foreign value added originated from US to China's export grew at astounding 180 percent between 2000 and 2007. However, between 2007 and 2018, the value only grew by 30 percent $^{6}$

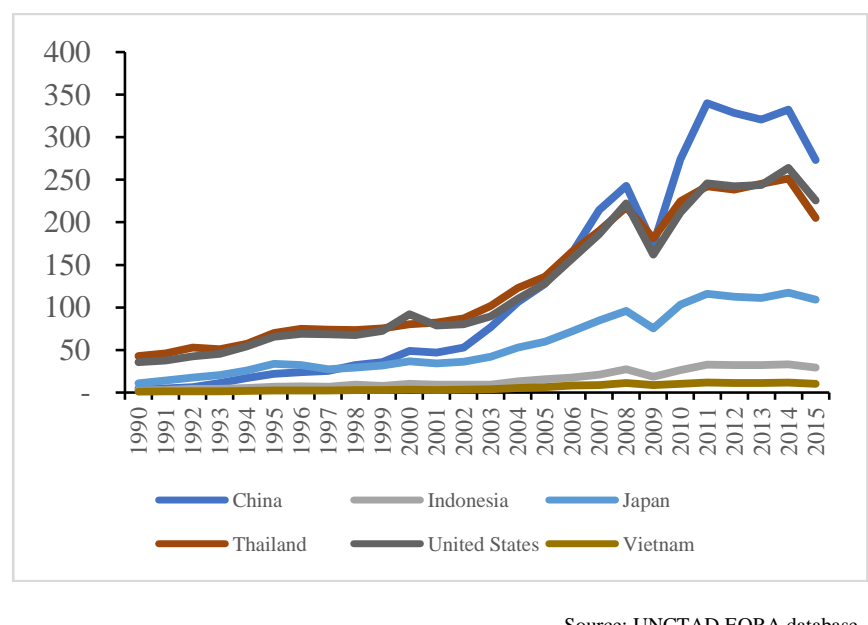

Fig. 1. Foreign Value Added in Trade, Current USD Million

Figure 1 also shows how Indonesia's position in the GVC is still low compared to other countries. As Kimura (2017) shows, foreign value-added in Indonesia's exports is very low - less than 10 percent for services and 20 percent in manufacturing. Moreover, in contrast to other neighboring countries, Indonesia has higher Forward Participation Index (FPI) than Backward Participation Index (BPI), implying that the country is mostly a raw material provider rather than downstream producer. Nevertheless, over 2012 to 2015, trade in machinery parts and components have been recently enhanced. Between this period, exported productdestination pairs of parts and components increased from 15,944 to 17,450 . However, should the pattern of declining fragmentation and maturation of GVC persist, it is a question whether Indonesia can still benefit from the opportunities provided by fragmentation of production processes.

In contrast to the pattern in trade in goods and GVC, it is worth noting that the long-run elasticity of trade in services have remained constant over time, staying at 2.1 during 1990s and 2000s. In terms of changes in the composition of aggregate demand, Timmer, et al (2016) also found that global demand has shifted to services. These patterns show that while trade in goods may relatively decline in its importance, the services sectors remain a promising source of development. Nevertheless, for the case of Indonesia, the services sector is still comprised by low-productivity jobs and constitutes small share of exports, albeit comprising largest share of GDP (its value-added reached 43.4 percent of GDP as of 2018). As Pangestu and Findlay (2016) shows, high restrictiveness compared to other countries in this sector have contributed to its relatively low level of development. The service value added embodied in manufacturing exports is also lowest in Indonesia compared to BRIICS economies, comprising only 21 percent of its manufacturing exports. 
Another issue worth mentioning with regard to the rise of China is the sign of its declining competitiveness. Between 2009 and 2017, its Incremental Capital-Output Ratio (ICOR) has tripled for the corporate sector, potentially as a result of over-borrowing $^{7}$. In 2008, the average monthly earning in current USD was $\$ 351$. By 2015 , it reached $\$ 830$, growing cumulatively 15 percent on average per year. By contrast, the figure of Indonesia was \$118 and \$136 for 2008 and 2015, respectively, with cumulative average growth rate of only 1.7 percent annually ${ }^{8}$. Moreover, between 2010 and 2017, the cumulative percent change of unit labor cost in China exceeded 60 percent (World Bank, 2019). The signs of declining competitiveness also appear in productivity figures. Between 2000 and 2007, the total factor productivity (TFP) grew by 29 percent from 0.7 to 0.9 . By contrast, between 2008 to 2017 , its TFP only grew at a lower 13.4 percent, from 0.92 to $1.04^{9}$

\section{B. Resort to Protectionism and US-China Trade War}

While the overall benefit of free trade is not questioned in the trade literature based on theories of gains for trade, the fact that free trade does not benefit all equally within a nation or between sectors, has always been part of the comparative advantage theory. Those factors or sectors who are less competitive will lose compared to the competitive sectors, and theory calls for compensation so that the result is a net benefit to trade. Autor, Dorn, and Hanson (2013) and Autor, et al. (2016) found such evidence, and the paper found that there is a strong association between exposure to trade with China with the US counties that saw a change from moderateleaning representatives and to more far-right or far-left representatives. When comparing districts in $75^{\text {th }}$ percentile of trade exposure with China against the district in $25^{\text {th }}$ percentile, the more exposed district would have had a 3.5 percentage points lower share of vote going to the incumbent party, and higher nominate score ${ }^{10}$, 'moving' representatives farther away from median political spectrum.

The findings provide some evidence on how trade may be detrimental to some particular group if the distributional impacts are not addressed properly, but does not in any way justify protectionist measures taken by developed countries such as the US. Nevertheless, it does give us an understanding of the background of the resentment felt in certain developed countries towards the current MTS and how it can cope with today's challenge. The issue of distributional implications of trade, especially with regard to the rise of developing countries, is in need of particular attention. It should also be noted, moreover, that the rise in anti-globalization worldwide are more pronounced in developed countries, including their lack of support of the WTO as the core of the multilateral trading system. In a recent survey conducted by Bertelsmann Stiftung, more than 60 percent of respondents in emerging countries believe the WTO is an important institution, while the number in the US is only 30 percent $^{11}$.
In many of the populist sentiments and rhetoric, dissatisfaction with WTO's "unfair" treatment of China and other developing county's trade practices are often cited.

The rise of protectionism occurred amidst growing perceptions that international trade led to loss of jobs, stagnation of the wages of the mid-level workers, and rising inequality, which worsened in the aftermath of the global financial crisis. The perception of these negative impacts was sharpened after the global financial crisis, even though studies show that technological change has been more the cause of the job losses and stagnating wages rather than trade. The subsequent anti-globalization and protectionist stance in the name of protecting jobs at home and in certain sectors became a compelling story, and as we have witnessed in the last few years, led to the election of leaders from far right or far left who tout a populist, nationalistic and protectionist stance. The election rhetoric of 2016 led to President Trump's first actions being President Trump actually enacting a series of actions to leave the TPP, renegotiate the North America Free Trade Agreement (NAFTA) and Korea US Free Trade Agreement (KORUS), and introduce an Executive Order to investigate 16 countries which the US has a trade deficit of which China was the largest. At the beginning of 2018 there was escalating protectionism with the imposition of tariffs unilaterally on steel and aluminum and raising tariffs to China's imports. The imposition of tariffs on steel and aluminum was based on section 232 of the US Trade Expansion Act (1962) or security grounds; while increased tariffs on China was not just on steel and aluminum, but on a range of other products deemed to be subjected to unfair trade practices ${ }^{12}$. As this paper was written, the US has already imposed on average 18.3 percent tariff on 50.6 percent of China's goods. On the other hand, China has imposed tariff on roughly 56 percent of US exports. The average tariff China imposes on the US as of August 2019 rose to 25.9 percent a sharp surge from pre-trade war level of 8 percent [7].

With no sight of ending of the 'tit-for-tat' tariff hike between US and China, the uncertainties it is causing is already beginning to affect world economic growth outlook. In July 2019, for example, the IMF once again revised its economic projection to 3.2 percent compared to 3.9 percent a year ago. The increased uncertainties surround the two major trading partners in the world, and the threat to the rules based multilateral trading system is a cause of great concern.

Indeed, Handley and Limao (2017) find that China's WTO accession significantly boosted exports to the US through reduction in US policy uncertainty. While it is true that most of the US-China trade boom occurred after China's accession, this does not necessarily imply that China's WTO accession boosted exports through reduction in trade barriers, as US-applied trade barriers toward China remained largely unchanged at that time. Instead, as the paper argues, it is the reduction of threat of US tariff against China that provides

\footnotetext{
https://chinapower.csis.org/china-economy-competitiveness/

${ }^{8}$ Author's calculation from ILOSTAT database

${ }^{9}$ Author's calculation from FRED

${ }^{10}$ The nominate score is a score ranking legislators on a liberalconservative scale according to their roll-call votes. See (Poole and Rosenthal, 1985 and 1991)
}

\footnotetext{
${ }^{11}$ Bertelsmann Stiftung. (2018). Revitalizing Multilateral Governance at the World Trade Organization.

12 The US also imposed safeguard duties on washing machine and solar panels, but at least they come under the purview of trade remedies, even though one could take issue with the investigation process.
} 
major boost to exports. By its accession protocol, China was ensured permanent MFN treatment which drastically reduces the threat of US tariffs against China's exports, at least before the 2016 US election. This is particularly crucial at the time of the accession, as in 1990 after the Tiananmen Square incident, the US congress voted on a bill to remove MFN status every year. Prior to that incident, China had obtained temporary MFN in 1980 and never lost it. To put it into context, the US MFN tariff in 2000 was at 4 percent, compared to average tariff of 31 percent that China would face if not granted the MFN tariff.

Although the current US-China trade escalation is worrisome to the overall growth trajectory of global economy, some countries may actually be benefited from the potential reallocation. For example, the value of US imports of goods from Thailand in 2018 that are included under US' first three tariff lists against China amounted to almost \$22.8 billion. The number for Viet Nam and India, on the other hand, are $\$ 18.7$ and $\$ 23.5$, respectively ${ }^{13}$. This indicates great potential reallocation for these developing countries. However, for the case of Indonesia, the number only reached $\$ 9.3$ billion, indicating low replacement potential. Other studies also confirm the potential relocation to Southeast Asia but not much to Indonesia. Abiad et al. (2018), for example, uses Multi-Regional Input Output Tables and found that the net effect of trade war on the rest of developing Asia turns mildly positive, at 0.06 percent under the 'current scenario' which includes all trade measures already implemented as of October 2018 - and 0.13 percent under the worse-case scenario - which features US-China full-blown escalation by assuming both countries impose 25 percent blanket tariffs on all of merchandise imports, as well as imposition of tariffs amounting 25 percent on global trade of autos, parts, and components by US and its trading partners. However, the number is negligible for the case of Indonesia. While countries such as Vietnam may experience 7.3 percent increase in exports under bilateral escalation scenario, Indonesia's export is only expected to rise by 0.8 percent.

The current situation in the US-China trade conflict is detrimental to the Multilateral Trading System not only because its direct economic impact of tariff escalation, but also on the uncertainty it creates regarding the global trade order as we know. The surge in uncertainty will likely increase stock price volatility, hamper investment, output, and eventually employment ${ }^{14}$. But not less important, it undermines the credibility of the current multilateral trading system to maintain an open, predictable, reciprocal trade relationship. We turn to this issue in the next sections.

\section{Increased Regionalism}

The current US stance on WTO of blocking the Appellate Body $(\mathrm{AB})$ judge nomination and wanting a change in the rules, is risking the breakdown of the Dispute Settlement system. However, although the approaches taken by the current US administration is 'unusual', the concerns on
WTO's ability in responding to current context of trade environment and global challenge is not new.

Prior to the seeming disruption of the "system", there have already been signs along the way regarding whether the MTS is fit for today's challenge given the stalling of the Doha Round of trade negotiations, the changing circumstances in terms of membership, issues that are increasingly affecting trade and investment but are not covered yet in the WTO, and issues raised regarding the institutional set up. However, its single-undertaking process makes it slow to respond to today's challenges. As such, in responding to the inflexibility of the WTO system, countries that are seeking deeper economic integration began to look at alternatives by undertaking bilateral, regional and mega-regional free trade agreements. The major regions such as the EU, Asia Pacific, East Asia, Southeast Asia and Latin America, all pursued bilateral as well as regional agreements, including expanding and deepening existing agreements. Apart from the intention of economic integration these agreements were of course also predicated by geo-political and strategic considerations.

Under the Obama administration (2008-2016) the US only turned seriously to trade policy in its second term, but focused on mega regional and bilateral agreements. The US began to promote Trans-Pacific Partnership (TPP) aggressively in 2012 and it was seen as the pivot to Asia and as a balance to the growing influence of China. In fact, President Obama explicitly stated that the TPP was intended so that China does not write the rules. During the same period the cross-Atlantic EU-US Transatlantic Trade and Investment Partnership (TTIP) was launched, focusing on regulatory harmonization rather than market access given the already low trade barriers between them. However, TTIP failed to make much progress, whereas the TPP after getting a boost with Japan joining in 2013 was concluded in 2015 . It was not ratified in Congress in time for the end of the Obama administration and as already mentioned, one of the first actions of President Trump upon assuming office in January 2017, was to leave the TPP.

Under the leadership of Japan, the remaining 11 members agreed to continue TPP without the US and negotiations were completed in 2018, and renamed Comprehensive and Progressive Trans-Pacific Partnership (CPTPP). Most countries have ratified the agreement and even though the economic size of the agreement is much smaller without the US, it is still a significant development and has been cited as the most ambitious regional agreement to date [12].

Besides CPTPP, in the Asia Pacific region, notably in East Asia, there has been a proliferation of bilaterals, and mega regionals. On the latter, in Southeast Asia, the ASEAN Free Trade Agreement progressed to go beyond tariffs and trade in goods, to become the ASEAN Economic Community in 2003. Furthermore, in the 2004-2009 period, ASEAN negotiated 5 free trade agreements or comprehensive economic partnerships with its main dialogue partners that not just focus on trade in goods, but also trade in services, investment, and increasingly added environment and labor

\footnotetext{
${ }^{14}$ For a discussion about the relationship between policy uncertainty
} measurement and these economic measures, see Handly and Limao (2017) 
issues, albeit still mainly on transparency issues. In 2012 ASEAN agreed to consolidate all the plus one agreement to become the East Asia Regional Comprehensive Economic Partnership (RCEP) agreement. Negotiations are still on going and apart from trade in goods, services and investment, there are chapters on competition policy, e-commerce, environment and labor, although it has been compared to be at a lower level of ambition compared to the CPTPP.

Although these partnerships are mainly intended to increase cooperation and economic integration among member states, the proliferation of regional agreements also potentially poses a threat WTO's non-discriminatory principle, as they are discriminatory in nature by providing preference on the insiders at the expense of outsiders. It also risks on creating stumbling blocks rather than building blocks for MTS negotiations with the emergence of the famous spaghetti bowl effect of inconsistent schedules and rules, and risks creating trade diversion. ${ }^{15}$ However, at the same time they could be catalysts to more multilateral agreements, and as a reference to new issues not yet addressed in the WTO, such as investment, data flows, and others.

\section{New Issues}

Another challenge of WTO's relevance comes from the changing pattern of international trade and that the WTO's rulebook is behind these developments. The last time the rules were negotiated and agreed upon was in 1995, and since then economies are much more integrated and production of goods and services much more fragmented. We now talk in terms of the global value chain as well as the digitalization of trade. Furthermore, the dichotomy of "north-south" or "developed-developing country" were still relevant at the time.

The trade rules and principles of today have not yet caught up with the digitalization of the economy and disruptions that have occurred in the way we produce, trade, interact, live and govern. While the MTS and free trade agreements have focused on the movement of trade in goods, trade in services, investment and capital flows, and flow of people, it is just beginning to address e-commerce and the flow of data.

Other than data flows, there have been pressures on the international community to commit on answering environment challenges and climate change. However, the existing WTO agreement does not provide any rulings on environment protection. It has been raised as a continuous debate whether the matter of environmental protection could fit somewhere in the scope of WTO law. Nevertheless, options are available in using WTO jurisdiction for environmental concerns.

Under the WTO declaration in Marrakesh agreement, sustainable development issues are specifically acknowledged. Paragraph 6 of the Doha Declaration even states the members' belief that the multilateral trade system, the protection of the environment and the promotion of sustainable development "can and must be mutually supportive."

One benefit of using WTO for environmental issues is that the WTO framework has sanction mechanism - which is at most, if not all, times lacking in intergovernmental and/or plurilateral initiatives on climate change. Such sanction mechanism is already in place in ASCM agreement. Although, ASCM is currently used for trade-related "injuries". The current framework however is inadequate to directly address these issues.

As an example, Pereira (2019) explores whether WTO jurisdiction can be applied for fossil fuels. The paper draws from the experience of fisheries negotiation to see the applicability of Fossil Fuel Subsidy Regulation under WTO framework. Looked at exclusively from a trade-distortion point of view, fossil fuel subsidies may not be justified to be treated differentially than other form of trade-distorting subsidies. However, to date, the dispute between European Union and its Member States - Certain Measures Relating to the Energy Sector (DS476) is the only dispute that directly challenges fossil fuel governmental subsidies. In contrast, at least seven disputes under the WTO dispute settlement system have targeted government policies that support the scaling up of renewable energy since 2010. Government support on renewables is often instead becoming targets of antidumping or countervailing duties issued by investigating authorities (Kampel 2017) or challenged at the DSB as inconsistent with WTO provisions.

\section{MOVING FORWARD: ADDRESSING THE CHALLENGES OF THE MTS}

Results of modeling and the geo strategic considerations point to a multi-prong strategy. The negative effects of U.S. protectionist measures could be mitigated by pursuing regional trade agreements with non-US regions. Pursuing trade agreements with non-U.S. regions and unilaterally liberalize tariffs on imports from the US found to be the most desirable strategy for developing countries, particularly for Latin America and the Caribbean [10]. An Australian Productivity Commission (2017) study also found similar results in that doing nothing amidst the trade war escalation (not retaliating or raising tariffs) would still hurt countries, but that if countries actually undertook unilateral reforms and even better enter into regional agreements, the impact turns to positive.

The result of the models and based on geostrategic considerations as well as past experience the three-prong strategy for countries would look something like this. Firstly, for countries like Indonesia and China, it is far more superior to undertake unilateral reforms on its own term and for its own purpose of development and structural change, as well as keeping up with the new issues, rather than face unilateral pressure to change based on one country's - that is the US frame. Thus, structural reforms in line with changing times should be prioritized. However, similar to global trend, for the case of Indonesia and other developing countries as well, 
more harmful trade interventions have been increasing over the years. Figure 2 shows that although "liberalizing" measures have grown rapidly since 2009, harmful interventions are still on the rise. As such, if Indonesia is to limit the negative impact of global trade uncertainty, this trend must first be reversed.

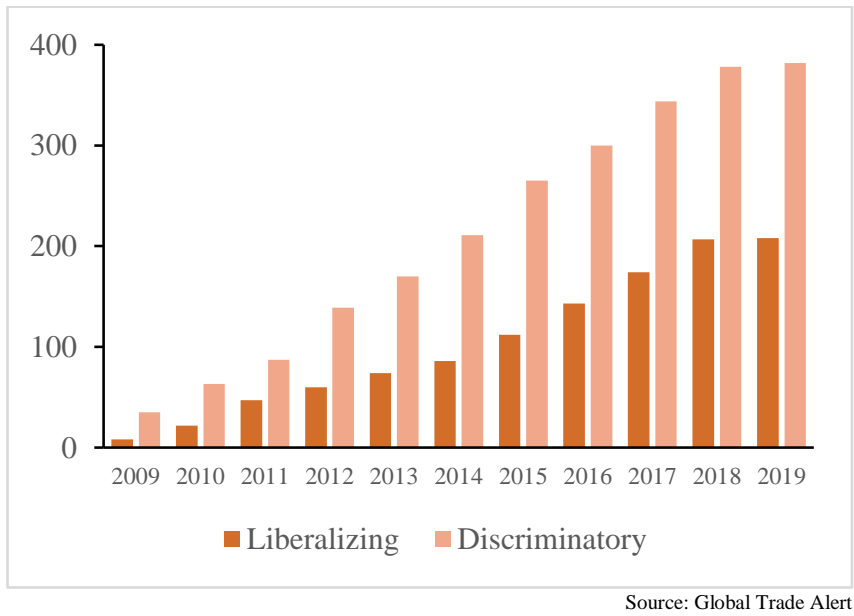

Fig. 2. Number of Trade Interventions Imposed by Indonesia

Second, signaling support on the process of opening up is important irrespective of the US stance. In the case of Indonesia and ASEAN, together with China, Japan and India, it is imperative that the East Asia Regional Comprehensive Economic Partnership (RCEP) negotiations are substantially completed this year. The expansion of markets between 16 economies making up half of the world's population, and 40 percent of world trade and GDP, should provide sources of growth and expansion of markets, as well as new configurations of the regional and global value chains.

Increasing regional integration will make it possible for countries to address current issues not yet addressed in the WTO. Currently, the WTO lacks the regulations related to ecommerce, data flows and data privacy [17]. Little progress also has been made by WTO agreements for the scope of ecommerce and internet-enabled transactions on goods and services. The concern of the rules also points to the lack of national enforcement in WTO members' jurisdictions towards providing measures for protected digital economies and foreign providers of goods and services. The recent announcement to begin negotiating a plurilateral agreement on e-commerce by 73 countries looks at many of these issues and is an important step of progress in the WTO negotiations framework, and having a plurilateral approach given the difficulties in reaching consensus amongst 164 members.

The most recent example of the inadequacy of WTO on answering this issue and how regional agreements discussed can answer this issue can be found in CPTPP and its farreaching agreements on today's landscape. Started to be in force by the end of 2018, the CPTPP chapters cover ranges of digital issues relevant to today's landscape. For example, the CPTPP made it clear that members may not discriminate against digital products, not to apply customs duties to digital products, and to protect source code, among others. The agreement also includes provisions that help ensure crossborder data flows continue unimpeded and that data centers cannot be required to be localized. The latter provision enables the continued use of cloud computing which is very important in today's economy [17].

Third, the most important issue is to address the great uncertainty that is being created with the new context of the US-China Trade war and US unilateralism. Countries like Indonesia face great uncertainty in the world trading climate and economy, which will have serious effect on its economy. Clearly a well-functioning rules-based open trading system is what businesses would like to have to address this uncertainty, yet it has been the major source of risk to growth. Amidst current uncertainties, it is too early to tell whether relocations within the global value chains will occur, but addressing uncertainty will surely create better investment atmosphere.

For developing countries like Indonesia, responding to 'unfair trade practices' is better done in the multilateral fora rather than be at the 'mercy' of bilateral negotiations with the US. It is also better that the issues that are at the heart of the US-China trade war - that is, issues related to intellectual property rights, technology transfer, industrial subsidies and other trade and investment distorting policies which affects the level playing field, be dealt with under a multilateral framework. We should be worried about US, China and any other large power's behavior without constraints of the multilateral trading system. Doing the bilateral deals approach will be harmful to the system as there will be an inclination for both US and China to do deals that are outside of the system, divert trade and undermine confidence in the WTO.

After 23 years since its foundation, for the first time the call for WTO reform was sounded at the G20 in Buenos Aires, December 2018. Leaders called for commitment to improve a "rules-based international order" that is capable of responding to the rapidly changing world and supported "the necessary reforms of the WTO" to improve its functioning.

The call for WTO reform proves as a signal that country leaders recognize that given the current changing global economic and political landscape, reform of the WTO to ensure the sustainability of a rule-based international trading system is of utmost importance. However, this is not so much reflected on the trade policies imposed by the signing countries. For example, since the G20 meeting in December 2018 to at least April 2019, the signing governments have imposed trade policies that is estimated to distort as much as US\$1.15 trillion worth of trade [14]. The figure is US\$250 billion larger than in the comparable period of the previous year. One may suspect that the surge in distorting trade policies witnessed in the first quarter of April must be due to the escalating tension of the Sino-US relationship. However, in contrary to that, the two countries were only responsible of 17 percent of the distortionary interventions implemented within December-April period. 
Figure 3 shows the number of harmful trade interventions implemented during $2019^{16}$. Although the US disproportionately impose much larger number of harmful trade interventions, China ranks only the $10^{\text {th }}$ of the largest imposer. The bulk of these harmful trade interventions are in subsidy measures (including export subsidies), comprising 38.5 percent of the total harmful interventions, followed by contingent trade-protective measures (anti-dumping, countervailing, and safeguard measures) comprising 19.7 percent of the harmful intervention. This pattern is also confirmed by WTO report that shows that through midOctober 2018 to mid-May 2019, G20 countries introduce on average three trade-restrictive measures per month [34].

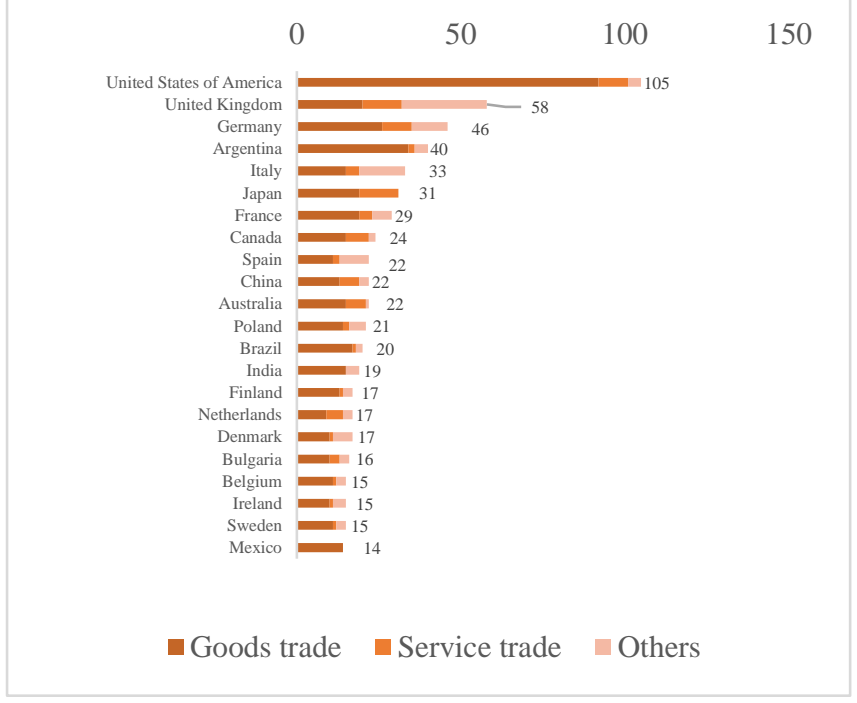

Source: Global Trade Alert

Fig. 3. Harmful Trade Interventions Imposed in 2019

It is important for countries to respond to current challenge by providing policy certainty by not increasing harmful trade intervention. For longer term issues, there should also be an ongoing and continued discussions on the more complex and potentially sensitive issues, which would a strategic process to strengthen the MTS and build confidence in the WTO process and institution. There is a range of new issues that fall into this category, ranging from traditional issues such as completing the agriculture negotiations, improving the rules on IPR, addressing services, and expanding the Government Procurement Agreement, to issues such as investment and investment facilitation, framework for trade distortions such as subsidies, competition policy and policy neutrality vis-à-vis StateOwned Enterprises, and to data flows and environment.

Nevertheless, while the issues described in the previous section will likely trigger another long process of negotiations, the more urgent issue of the nomination of judges for the Appellate Body needs to be prioritized. This include other reforms of the dispute settlement mechanism while at the same time addressing the proposed reforms which are already on the table to address the US Concerns. The concerns that needs to be addressed relate to the transition period of the $\mathrm{AB}$ judges, timelines for rulings and the issue of precedence, among others.

Furthermore, to ensure confidence in the WTO, there should be political will to resolve outstanding issues which are already well advanced in the process of negotiations. Two such possibilities are the completion of the rules on discipline on harmful fishing subsidies and transparency and notification of trade policies and WTO commitments. The former will both address market distortions as well as have sustainable outcomes on over-fishing and over capacity issues. The completion of the negotiation will set precedence on how the WTO framework and jurisdiction can address environment and sustainable development issues.

\section{CONCLUSION}

The US-China trade war and the US' hard stance on the credibility of the WTO comes in the age when global trade pattern has drastically change. While trade now contributes less for income generation, and the opportunities provided by fragmentation of global production starts to diminish, the policy uncertainty created by the trade war is the least countries can expect. As such, it is of utmost importance for countries to take actions to safeguard the MTS and reduce these policy uncertainties.

This paper has explored the options through which countries, especially developing countries, can navigate through current challenges. Structural reforms taken unilaterally, increasing regional partnership, and reducing uncertainty in multilateral fora are the main policy stances that countries should take. The current challenge on the MTS also needs to be seen as an opportunity to address issues that are long overdue. While the current US' stance and the policy actions are new, the concerns underlying the resentment towards the WTO are not. There needs to be both a top down and bottom up, and ongoing process that addresses the urgent issues and more longer-term issues of strengthening the MTS, as well as making the MTS relevant. The recommendation for top down comes from the highest level of political leadership which can call for the concerted action through the G20 process. The bottom up can come from various pathways, including plurilateral approaches, which can all be complementary rather than competing, and should all be pursued as mutual building blocks. This can start from the various Sherpa and working groups in the G20 that feeds into the WTO negotiating process.

\section{REFERENCES}

[1] Abiad, A., Baris, K., Bernabe, J. A., Bertulfo, D. J., Camingue, S., Feliciano, P. N., ... \& Mercer-Blackman, V. (2018). The Impact of Trade Conflict on Developing Asia. Asian Development Bank Economics Working Paper Series, (566).

[2] Amiti, M., \& Konings, J. (2007). Trade liberalization, intermediate inputs, and productivity: Evidence from Indonesia. American Economic Review, 97(5), 1611-1638.Baldwin, R. (2016). The great convergence. Harvard University Press.

[3] Australia Productivity Commission, Rising Protectionism: Challenges, Threats and Opportunities for Australia, July 2017

[4] Autor, D., Dorn, D., Hanson, G., \& Majlesi, K. (2016). Importing political polarization? The electoral consequences of rising trade 
exposure(No. w22637, pp. 936-953). Cambridge, MA: National Bureau of Economic Research.

[5] Bertelsmann Stiftung. (2018). Revitalizing Multilateral Governance at the World Trade Organization. Retrieved from https://www.bertelsmann-

stiftung.de/fileadmin/files/BSt/Publikationen/GrauePublikationen/MT _Report_Revitalizing_Multilateral_Governance_at_the_WTO.pdf

[6] Birdsall, et al. (1993). The East Asian miracle: economic growth and public policy. A World Bank policy research report. New York, New York: Oxford University Press. http://documents.worldbank.org/curated/en/975081468244550798/Ma in-report

[7] Bown, C. P. (2017). Mega-Regional Trade Agreements and the Future of the WTO. Global Policy, 8(1), 107-112.

[8] Cristina Constantinescu, Aaditya Mattoo, Michele Ruta, The Global Trade Slowdown: Cyclical or Structural?, The World Bank Economic Review, , lhx027, https://doi.org/10.1093/wber/lhx027

[9] David, H., Dorn, D., \& Hanson, G. H. (2013). The geography of trade and technology shocks in the United States. American Economic Review, 103(3), 220-25.

[10] Devarajan, S., Go, D. S., Lakatos, C., Robinson, S., \& Thierfelder, K. (2018). Traders' Dilemma: Developing Countries' Response to Trade Disputes. The World Bank.

[11] Dutt, P., Mihov, I., \& Van Zandt, T. (2013). The effect of WTO on the extensive and the intensive margins of trade. Journal of international Economics, 91(2), 204-219.

[12] Elms. (2019). The Comprehensive and Progressive Trans-Pacific Partnership. Bertelsmann Stiftung

[13] Epstein, J. (2018, June 3). Trump Says WTO Is Treating the U.S. 'Very Badly' Despite Wins. Bloomberg. Retrieved from https://www.bloomberg.com

[14] GTA. (2019). Jaw Jaw not War War: Prioritising WTO Reform Options

[15] Handley, K., \& Limão, N. (2017). Policy uncertainty, trade, and welfare: Theory and evidence for china and the united states. American Economic Review, 107(9), 2731-83.

[16] Hu, K. (2018, June 1). Why the $\$ 375$ billion US-China trade deficit can be totally misleading. Yahoo Finance. Retrieved from https://finance.yahoo.com/

[17] Hodson, S. (2018). Applying WTO and FTA Disciplines to Data Localization Measures. World Trade Review, 1-29.

[18] Hufbauer, G. C., \& Cimino-Isaacs, C. (2015). How will TPP and TTIP Change the WTO System?. Journal of International Economic Law, 18(3), 679-696.

[19] Hufbauer, G. C., \& Kim, J. (2009). The World Trade Organization and climate change: Challenges and options (No. WP09-9). Washington, DC: Peterson Institute for International Economics.

[20] Kampel, K. 2017. Options for Disciplining the Use of Trade Remedies in Clean Energy Technologies. Geneva: International Centre for Trade and Sustainable Development (ICTSD).

[21] Kee, H. L., \& Tang, H. (2015). Domestic value added in exports: Theory and firm evidence from China. The World Bank.

[22] Kim, B. (2017). What has China Learned from Processing Trade? Journal of Economic Structures, 6(1), 32.

[23] Kimura, F., \& Chen, L. (2018). Value Chain Connectivity in Indonesia: The Evolution of Unbundlings. Bulletin of Indonesian Economic Studies, 54(2), 165-192.

[24] Milanovic, B. (2016). Global inequality: A new approach for the age of globalization. Harvard University Press.

[25] Pangestu, M., Armstrong, S. (2018). Asian Integration: the State of Play, in S. Armstrong \& T. Westland (eds). Asian Economic Integration in an era of Global Uncertainty. ANU Press 2018.

[26] Pangestu, M., and Findlay, C. (2016). The services sector as a driver of change: Indonesia's experience in the ASEAN context. Bulletin of Indonesian Economic Studies, 52(1), 27-53.

[27] Pangestu, M., Rahardja, S., \& Ing, L. Y. (2015). Fifty years of trade policy in Indonesia: New world trade, old treatments. Bulletin of Indonesian Economic Studies, 51(2), 239-261.

[28] Pereira, H. (2018). How the WTO can help tackle climate change through fossil fuel subsidy reform. ICTSD
[29] Poole, Keith T., and Howard Rosenthal. 1985. "A Spatial Model for Legislative Roll Call Analysis." American Political Science Review, 29(2): 357-384

[30] Poole, Keith T., and Howard Rosenthal. 1991. "Patterns of Congressional Voting." American Journal of Political Science, 35(1): 228-278.

[31] Stiglitz, J. E., \& Yusuf, S. (Eds.). (2001). Rethinking the East Asian Miracle. The World Bank.

[32] Timmer, M., Los, B., Stehrer, R., \& de Vries, G. (2016). An anatomy of the global trade slowdown based on the WIOD 2016 release (No. GD-162). Groningen Growth and Development Centre, University of Groningen.

[33] Viner, J. (1950). The Customs Union Issue. New York: Carnegie Endowment for International Peace.

[34] WTO. (2019). Report on G20 Trade Measure. 